\title{
Arthropods of forestry and medical-veterinary importance in the Limarí basin (Coquimbo region, Chile)
}

\section{Jaime Pizarro-Araya ${ }^{1,2,3}$, Fermín M. Alfaro ${ }^{1,2,3}$, Rodrigo A. Muñoz-Rivera ${ }^{4,5}$, Juan E. Barriga-Tuñón ${ }^{6}$, and Luis Letelier ${ }^{7,8}$}

${ }^{1}$ Universidad de La Serena, Facultad de Ciencias, Departamento de Biología, Laboratorio de Entomología Ecológica. Casilla 554, La Serena, Chile.

${ }^{2}$ Universidad de La Serena, Instituto de Investigación Multidisciplinar en Ciencia y Tecnología. Casilla 554, La Serena, Chile.

${ }^{3}$ Grupo de Artrópodos, Sistema Integrado de Monitoreo y Evaluación de Ecosistemas Forestales Nativos (SIMEF), Chile.

${ }^{4}$ Universidad de La Serena, Facultad de Ciencias, Departamento de Agronomía, Laboratorio de Prospección, Monitoreo y Modelación de Recursos Agrícolas y Ambientales (PROMMRA). Ovalle, Chile.

${ }^{5}$ Departamento de Investigación y Desarrollo, AnRos Asesorías Agronómicas SpA. Gordon Steel 3849 Costa Palermo 2, Coquimbo, Chile.

${ }^{6}$ Universidad Católica del Maule, Facultad de Ciencias, Agrarias y Forestales, Departamento de Ciencias Agrarias. Casilla 139, Curicó, Chile.

${ }^{7}$ Universidad Bernardo O’Higgins, Centro de Investigación en Recursos Naturales y Sustentabilidad (CIRENYS). Casilla 913322, Santiago, Chile.

${ }^{8}$ Universidad de Talca, Instituto de Ciencias Biológicas y Núcleo Científico Multidisciplinario. 1 Poniente 1141, Casilla 747-721, Talca, Chile.

\begin{abstract}
J. Pizarro-Araya, F.M. Alfaro, R.A. Muñoz-Rivera, J.E. Barriga-Tuñon, and L. Letelier. 2019. Arthopods of forestry and medical-veterinary importance in the Limarí basin (Coquimbo region, Chile). Cien. Inv. Agr. 46(1): 40-49. The Limarí River valley, located in the Coquimbo Region of Chile, is an important area for agricultural production that pertains to the transverse valleys ecoregion, known as Norte Chico. In recent decades, the continuous expansion of agriculture towards the dryland areas has favored the introduction and establishment of potential pests, such as arthropods, that may affect forestry crops and transmit zoonotic diseases. We analyzed the arthropod assemblages that were of forestry and medical-veterinary importance in the Limari basin. After reviewing historical data, specimen collections, and the available literature, a total of 10 families, 39 genera, and 51 species of arthropods of forestry importance were recorded, $43.1 \%$ of which were of quarantine importance. Xylophagous groups of quarantine importance to the US included Cryptotermes brevis (Kalotermitidae), Neoterius mystax (Bostrichidae), Tyndaris planata (Buprestidae), Rhyephenes humeralis (Curculionidae) and Phoracantha recurva (Cerambycidae). Other quarantine insects of forestry importance recorded in the area included were Micrapate scabrata and Polycaon chilensis (Bostrichidae). In addition, the groups of medical-veterinary importance were represented by 11 families, 14 genera, and 18 species, 9 of which were arachnids and 9 were insects. Among the identified arachnids, the most important genera were Loxosceles (Sicariidae), Latrodectus, Steatoda (Theridiidae) and Rhipicephalus (Ixodidae), whereas among the identified insects, the most important were Triatoma and Mepraia (Reduviidae), Pediculus (Pediculidae), and Ceratophyllus (Ceratophyllidae). We hope this study serves as a basis for the development of forest pest monitoring and control programs as well as an understanding of the potential risks posed by zoonotic agents and their implications for public health.
\end{abstract}

Key words: Agricultural cropland, arid zones, arthropods, Limarí Valley, Norte Chico.

Received Nov 28, 2017. Accepted Mar 19, 2019.

Corresponding author: japizarro@userena.cl 


\section{Introduction}

One of the first studies to document potential pests in a valley of Chile's Norte Chico was conducted by Pizarro-Araya et al. (2009) in three localities of the Elqui Valley (Coquimbo Region). These authors recorded 181 arthropod species, 145 of which were insects and 36 were spiders. Among these arthropods, 36 insects and 1 mite were considered pests of agricultural importance that attack one or more host plants (e.g., Macrosiphum, Rhopalosiphum, Myzus, Coccus, Pseudococcus). The authors also identified species of medical importance, such as Loxosceles, Latrodectus, Triatoma, and Mepraia. In this same valley, Alfaro et al. (2011) examined the taxonomic composition and abundance of the assemblage of Orthoptera (Insecta), correlating spatial distributions via the NDVI (Normalized Difference Vegetation Index). This was the first attempt at identifying potential pest orthopterans (e.g., Schistocerca cancellata, Conometopus sulcaticollis, Gryllus fulvipennis) in this basin of the Coquimbo Region. Following the same line as these two previous studies (see Pizarro-Araya et al., 2009; Alfaro et al., 2011) that have examined the biological vulnerabilities of the basins of the semiarid region of Chile, the objective of this work was to examine the forestry and medical-veterinary importance of arthropods in the Limarí River basin (Coquimbo Region, Chile).

\section{Materials and Methods}

Study area

The study area encompassed the three basins associated with, or influenced by, the Limarí River; they were the basin of the Limarí River itself, the coastal basin of the Elqui and Limari rivers, and the coastal basin of the Limarí and Choapa rivers (Álvarez, 2018). The limits of these three basins were defined by the Instituto Geográfico Militar (IGM) at a 1:250,000 scale (Shapefile)(Figure 1). The predominant soil types in the area were entisols, aridisols, and inceptisols, all of which showed some influence from the prevailing vegetation (Morales et al., 2006). The climate was categorized by steppe type and ranged from steppes with abundant clouds on the coast to cold steppes in the mountains (Novoa and López, 2001). The mean annual precipitation exceeded $300 \mathrm{~mm}$ in the mountainous areas and reached $60-240 \mathrm{~mm}$ in lower sectors that were near the coast (DMC, 2001). The annual temperature was homogeneous in the coastal areas but varied in the interior valleys and mountainous areas (DMC, 2001). The vegetation in the interior areas was free from the influence of the sea and corresponded to an interior steppe scrubland (Gajardo, 1993; Squeo et al., 2001).

\section{Capture methods and data collection}

To identify the arthropods of forestry and medicalveterinary importance in the Limarí basin, the distributional data of arthropods of economic importance were collected by reviewing reference materials that were deposited in the following entomological collections: Juan Enrique Barriga Collection (JEBC); Laboratorio de Entomología Ecológica, Universidad de La Serena, La Serena, Chile (LEULS); and Museo Entomológico Luis Peña, Departamento de Sanidad Vegetal, Facultad de Ciencias Agronómicas, Universidad de Chile, Santiago, Chile (MEUC). Additionally, the Servicio Agrícola y Ganadero de Chile (SAG) provided data from their entomological records for Limarí Province that were obtained between 2009 and 2015. These records were complemented with distribution data that were obtained from the literature, manual collections, and net (Bioquip, Extra soft aerial bag, $38 \mathrm{~cm}$ net ring diameter) and UV light (166 LED light, 12 volt) captures that were conducted between June and October 2015. The captured material was cleaned, dried, and preserved in alcohol (70\%) until processing and mounting. All the collected material was deposited at the Laboratorio de Entomología Ecológica of the Universidad de La Serena 


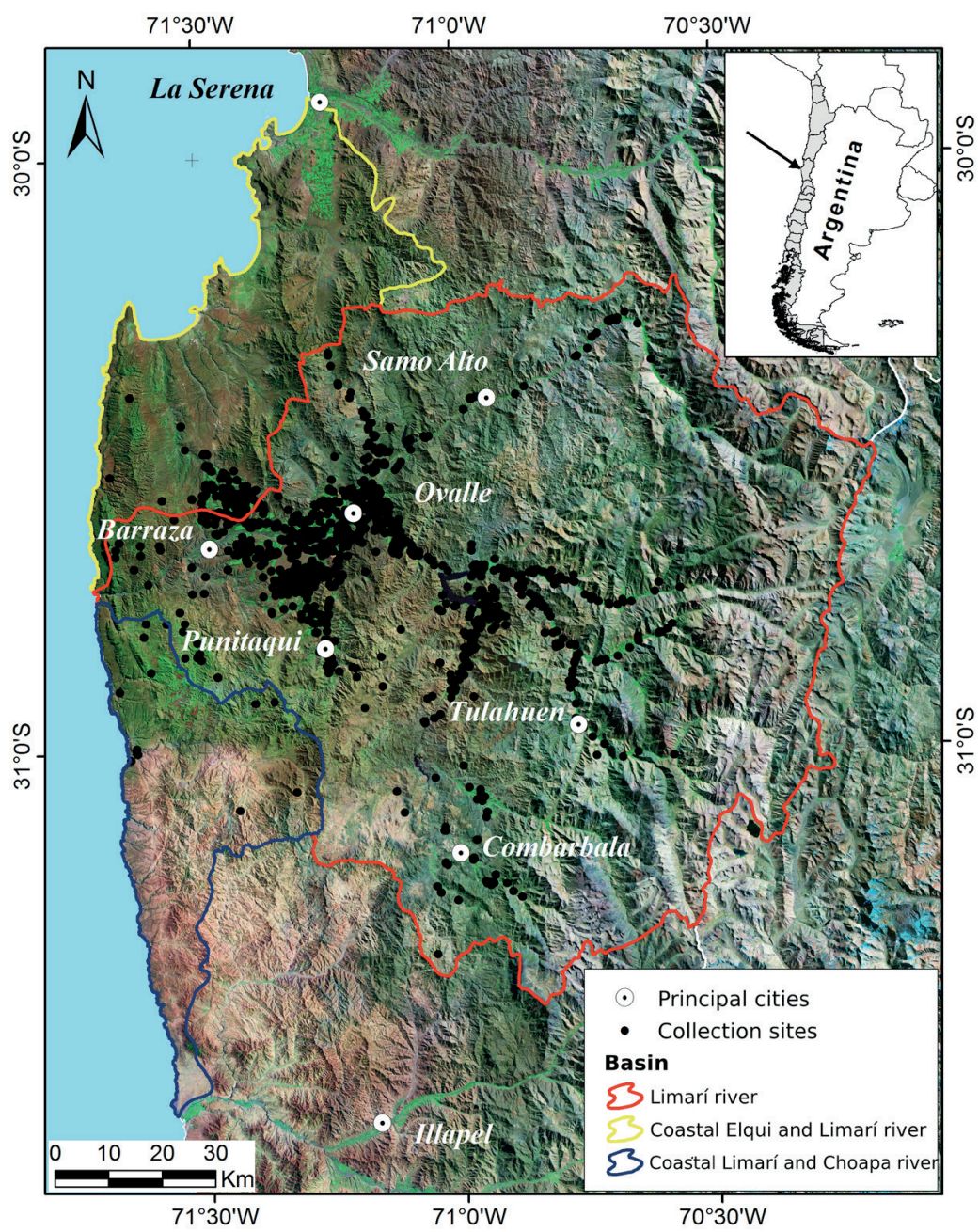

Figure 1. Geographical location of the Limarí basin (Coquimbo Region, Chile) and spatial records of arthropods of economic importance used in this study.

(LEULS). The taxonomic identification of the arthropods followed the guidelines of associated, specialized literature.

\section{Results and Discussion}

\section{Arthropods of forestry importance in the Limari basin}

The records analyzed during this study included a total of 10 families, 39 genera, and 51 species of arthropods of forestry importance, $43.1 \%$ of which were of quarantine importance. The xylophagous coleopterans of quarantine importance to the US that were recorded in the Limarí basin included the genera Bilyaxia spp. (Buprestidae), Mordella spp. (Mordellidae), and Neotermes spp. (Kalotermitidae). The xylophagous species of quarantine importance to the Limarí basin included Lyctus chilensis Gerberg and Neoterius mystax (Blanchard) (Bostrichidae), Tyndaris planata (Laporte and Gory) (Buprestidae), and Rhyephenes humeralis Guérin-Méneville (Curculionidae). We also recorded the presence of the hymenopteran Nematus oligospilus Foerster (Tenthredinidae) and the isopteran Cryptotermes brevis (Walker) (Kalotermitidae), both of quarantine importance to the US. Lastly, the recorded species in the area 
included the introduced cerambycids Phoracantha semipunctata Fabricius and Phoracantha recurva Newman, xylophagous species that feed on $\mathrm{Eu}$ calyptus spp. (Table 1) with a wide distribution in the basins of semiarid Chile. At present, $P$. semipunctata is an A1 quarantine pest for Asia (Bahrain) and Canada, an A2 quarantine pest for Africa (East Africa and Southern Africa) and a target of the Inter-African Phytosanitary Council (IAPSC). On the other hand, P. recurva is a quarantined species in the US; however, it was deleted from the EPPO Alert List in 2006. The main purpose of the Alert List is to draw the attention of EPPO member countries to certain pests that might present a risk to them, achieving early warning (EPPO, 2019). Regarding $P$. semipunctata, Lanfranco and Dungey (2001) note that this species is a threat only in the arid and semiarid regions of Chile, where Eucalyptus spp. are subject to high water stress. The main eucalyptus species that are used as a host plant by $P$. semipunctata include E. globulus, E. camaldulensis, and $E$. delegatensis, although damage has also been observed in E. nitens, E. gunnii, and E. viminalis. $P$. semipunctata damage is caused by galleries that are excavated by the larvae when they attack the phloem of green or recently cut wood (Paine et al., 2011).
Other xylophagous coleopteran species that were widely distributed in the Limarí basin included Dexicrates robustus (Blanchard), Micrapate scabrata (Erichson) and Polycaon chilensis (Erichson) (Bostrichidae) (quarantine pests for United States), Nathrius brevipennis (Mulsant) and Neohebestola viticollis (Blanchard in Gay) (Cerambycidae) (quarantine pest for United States), Calymmaderus sericeus Pic (Ptinidae), Oryctomorphus bimaculatus Guérin-Méneville (Scarabaeidae) (quarantine pest for United States), and Scolytus rugulosus (Müller) (Scolytidae) (Table 1).

Arthropods of medical-veterinary importance in the Limari basin

The arthropods of medical-veterinary importance are represented by both arachnids and insects and include a total of 11 families, 14 genera, and 18 species, 9 of which are arachnids and 9 are insects. Within the Arachnida, Loxosceles laeta (Nicolet) (Sicariidae) is the main zoonotic spider in the Limarí basin. Its distribution range encompasses agricultural ecosystems, drylands, and houses (Table 2) (Pizarro-Araya et al., 2009; Alcayaga et al., 2013). The condition caused by the bite of this spider, known as loxocelism, is an

Table 1. Records of insects (Insecta) of forestry importance found in the Limarí basin (Coquimbo Region, Chile): the scientific name, source, and economic importance are indicated. EEC = European Economic Community; $1=\mathrm{SAG} ; 2=$ JEBC; 3 = LEULS; 4 = MEUC.

\begin{tabular}{|c|c|c|c|c|}
\hline Order & Family & Scientific name & Source & Economic importance \\
\hline \multirow[t]{6}{*}{ Coleoptera } & Bostrichidae & Chilenius spinicollis & 2 & Xylophagous \\
\hline & & Dexicrates robustus & $1,2,3$ & $\begin{array}{c}\text { Xylophagous and polyphagous (dead wood, } \\
\text { occasionally young plants with colihue stakes). A } \\
\text { quarentenary species to the US. }\end{array}$ \\
\hline & & Lyctus chilensis & 3 & $\begin{array}{l}\text { Polyphagous and xylophagous (dead wood, mainly } \\
\text { burnt plants) }\end{array}$ \\
\hline & & Micrapate humeralis & 2 & Xylophagous \\
\hline & & Micrapate scabrata & 1,3 & $\begin{array}{l}\text { Polyphagous and xylophagous (dead or debilitated } \\
\text { wood); affects vines and other species. A quarentenary } \\
\text { species to the US }\end{array}$ \\
\hline & & Neoterius mystax & 1 & Xylophagous. A quarentenary species to the US \\
\hline
\end{tabular}




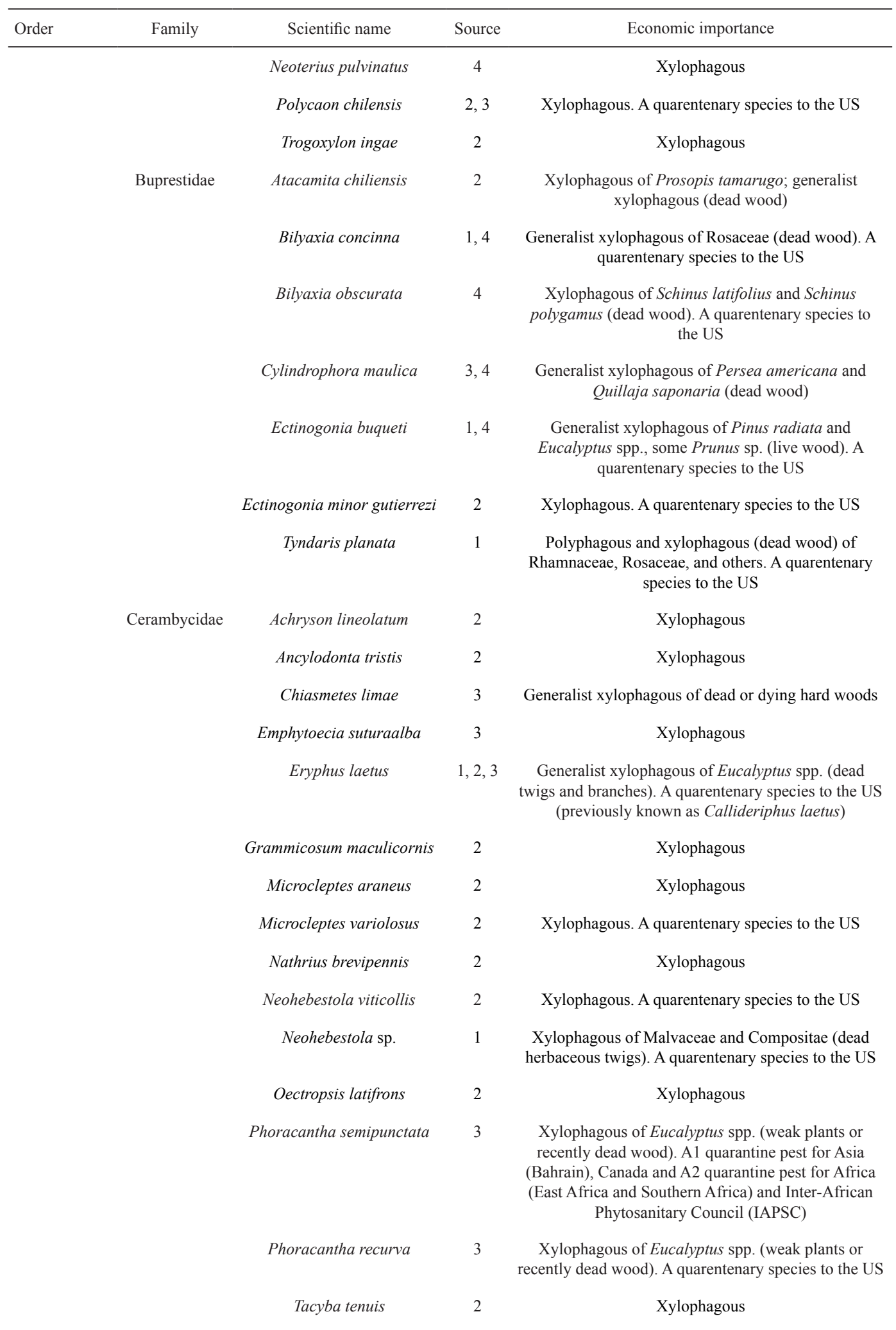




\begin{tabular}{|c|c|c|c|c|}
\hline Order & Family & Scientific name & Source & Economic importance \\
\hline & & Tillomorpha lineoligera & 2 & Xylophagous \\
\hline & & Xenocompsa flavonitida & 2 & Xylophagous \\
\hline & & Xenocompsa semipolita & 2 & Xylophagous \\
\hline & Curculionidae & $\begin{array}{l}\text { Apocnemidophorus } \\
\text { variegatus }\end{array}$ & 2,4 & $\begin{array}{c}\text { Phytophagous and xylophagous of Lithrea caustica } \\
\text { and Schinus latifolius }\end{array}$ \\
\hline & & Rhyephenes humeralis & 1,3 & $\begin{array}{l}\text { Generalist xylophagous of Pinus radiata and } \\
\text { Pseudotsuga menziesii. A quarentenary species to the } \\
\text { US }\end{array}$ \\
\hline & & Scolytus rugulosus & 1 & Xylophagous of debilitated Prunus sp. \\
\hline & & Xylechinus sp. & 2 & Xylophagous \\
\hline & Mordellidae & Mordella luctuosa & 1 & $\begin{array}{c}\text { Xylophagous of rotting wood. Mordella is a } \\
\text { quarentenary genus to the US }\end{array}$ \\
\hline & & Mordella sp. & 2 & $\begin{array}{c}\text { Xylophagous of rotting wood. A quarentenary species } \\
\text { to the US }\end{array}$ \\
\hline & & Mordellistena sp. 3 & 2 & Xylophagous of herbs \\
\hline & & Mordellistena sp. 9 & 2 & Xylophagous of herbs \\
\hline & Ptinidae & Calymmaderus sericeus & 2 & Xylophagous \\
\hline & & Calymmaderus sp. & 1 & Xylophagous \\
\hline & & Stichtoptychus brevicollis & 2 & Xylophagous \\
\hline & Scarabaeidae & Oryctomorphus bimaculatus & 3 & $\begin{array}{c}\text { Xylophagous of rotting wood. A quarentenary species } \\
\text { to the US }\end{array}$ \\
\hline & & Oryctomorphus maculicollis & 3 & Xylophagous of Puya chilensis (dead stems) \\
\hline Hymenoptera & Siricidae & Tremex fuscicornis & 1 & Xylophagous \\
\hline \multirow[t]{2}{*}{ Isoptera } & Kalotermitidae & Cryptotermes brevis & 3 & Xylophagous. A quarentenary species to the US \\
\hline & & Neotermes chilensis & 1 & Xylophagous. A quarentenary species to the US \\
\hline Lepidoptera & Cossidae & Chilecomadia sp. & 1,3 & $\begin{array}{c}\text { Xylophagous of numerous plants. A quarentenary } \\
\text { species to the US }\end{array}$ \\
\hline
\end{tabular}

important disease in the area as a result of the high morbidity and mortality of the venom of this species, which has dermonecrotic, hemolytic, vasculitic, and coagulant effects (Parra et al., 2002; Zambrano et al., 2005). The LEULS has a few specimens of Loxosceles spp., most likely Loxosceles coquimbo (Gertsch) (A.D. Brescovit com. pers.), an endemic species of Elqui Province, Coquimbo Region.

Among the taxa of Sicariidae, the genus Sicarius Walckenaer is the most abundant and widely distrib- uted of the spider assemblage. Sicarius individuals have errant habits and remain partially buried in the sand or under rocks, in places protected from the high solar radiation. Their bite is necrotic (LlinasGutiérrez et al., 2004). The most important member of Theriidae is the black widow, Latrodectus sp., a zoonotic and phanerotoxic spider whose bite causes latrodectism (Canals et al., 2004; Matteucci et al., 2005). Its venom contains several neurotoxins that may cause a complex array of clinical symptoms (e.g., rapid heartbeat, high blood pressure, and priapism) or even death (Romero et al., 2000; Alcayaga et al., 
Table 2. Records of insects (Insecta) of medical-veterinary importance found in the Limarí basin (Coquimbo Region, Chile): the scientific name, source, and economic importance are indicated. 1=SAG; $2=$ LEULS; $3=$ MEUC.

\begin{tabular}{|c|c|c|c|c|c|}
\hline Class & Order & Family & Scientific name & Source & Economic importance \\
\hline \multirow[t]{9}{*}{ Arachnida } & Acari & Ixodidae & $\begin{array}{l}\text { Rhipicephalus } \\
\text { sanguineus }\end{array}$ & 2 & Babesiosis in dogs \\
\hline & Araneae & Scytodidae & Scytodes globula & 2 & Predator of Loxosceles sp. \\
\hline & & Sicariidae & Loxosceles laeta & 2 & $\begin{array}{c}\text { Loxoscelism; predator of Scytodes } \\
\text { spp. }\end{array}$ \\
\hline & & & Loxosceles sp. & 2 & $\begin{array}{c}\text { Loxoscelism; predator of Scytodes } \\
\text { spp. }\end{array}$ \\
\hline & & & Sicarius sp. & 2 & Predator of insects and spiders \\
\hline & & Theridiidae & Latrodectus sp. & 2 & Latrodectism \\
\hline & & & Steatoda grossa & 2 & Steatodism \\
\hline & & & Steatoda porteri & 2 & Steatodism \\
\hline & & & Steatoda nobilis & 2 & Steatodism \\
\hline \multirow[t]{9}{*}{ Insecta } & Blattodea & Blattidae & Blatta orientalis & 2 & Parasite and disease vector \\
\hline & Hemiptera & Reduviidae & Mepraia spinolai & 2 & American trypanosomiasis \\
\hline & & & $\begin{array}{l}\text { Triatoma } \\
\text { infestans }\end{array}$ & 3 & American trypanosomiasis \\
\hline & Diptera & Drosophilidae & $\begin{array}{l}\text { Drosophila } \\
\text { melanogaster }\end{array}$ & 1 & $\begin{array}{l}\text { Polyphagous and phytophagous; } \\
\text { Vector of pathogenic bacteria }\end{array}$ \\
\hline & & & Drosophila sp. & 1 & $\begin{array}{l}\text { Polyphagous and phytophagous; } \\
\text { Vector of pathogenic bacteria }\end{array}$ \\
\hline & & Muscidae & Musca domestica & 1 & Vector of diseases \\
\hline & Hymenoptera & Formicidae & Dorymyrmex sp. & 1 & Potential vector of diseases \\
\hline & Siphonaptera & Ceratophyllidae & $\begin{array}{l}\text { Ceratophyllus } \\
\text { gallinae }\end{array}$ & 2 & $\begin{array}{c}\text { Ectoparasite of Gallus gallus } \\
\text { domesticus }\end{array}$ \\
\hline & Phthiraptera & Pediculidae & $\begin{array}{l}\text { Pediculus } \\
\text { humanus }\end{array}$ & 2 & Head lice infestations \\
\hline
\end{tabular}

2013). We also recorded false black widows, spiders belonging to the genus Steatoda Sundevall, whose bite causes steatodism, a zoonosis characterized by mild to severe regional pain, nausea, headache, general discomfort, and lethargy (Faúndez and Téllez, 2016). We also recorded Steatoda grossa (C. L. Koch), S. porteri (Simon), and S. nobilis (Thorell) in the Limarí basin, with $S$. nobilis being the first record of this species in the Coquimbo Region (Table 2).

The order Acari, represented by the brown dog tick Rhipicephalus sanguineus (Latreille) (Ixodidae), was recorded along the entire Limarí basin. Tick specimens were collected from dogs (Canis familiaris Linnaeus) and were associated with dryland areas, although adult specimens have also been collected from goats (Capra hircus Linnaeus) (González-Acuña et al., 2006). This species is univoltine and is active during the spring-summer. Diapause typically occurs during the adult stage and, secondarily, during the nymphal stage (Table 2).

Regarding Insecta, the presence of Triatoma infestans (Klug) and Mepraia spinolai (Porter) (Hemiptera: Reduviidae) in dryland areas of the Limarí basin suggests the existence of foci of American trypanosomiasis (Chagas disease). This disease poses a risk to the human population and is one of the more prevalent zoonotic diseases in the Norte Chico of Chile (Frías et al., 1998; Ortiz 
et al., 2016). In this respect, Chacón et al. (2016) indicated that the most frequent feeding source used by Trypanosoma cruzi was Phyllotis darwini (Waterhouse), followed by Octodon degus (Molina), Oryctolagus cuniculus (Linnaeus), Mus musculus Linnaeus, Gallus gallus Linnaeus, Thylamys elegans Waterhouse, Canis familiaris Linnaeus, Felis catus Linnaeus and Capra hircus Linnaeus. All these taxa are distributed along the entire Limarí basin.

Another insect of medical-veterinary importance recorded in the study area was Pediculus humanus Haeckel (Phthiraptera: Pediculidae), an ectoparasite of humans that causes head lice infestation (Rosso et al., 2003). Finally, Ceratophyllus gallinae (Schrank) (Siphonaptera: Ceratophyllidae) was recorded from poultry (Gallus gallus domesticus Linnaeus) (Table 2).

The main conclusions are the following. The richness of arthropods of forestry and medicalveterinary importance in the Limarí basin included mainly insects. The elements that were of forestry importance included insect species that were widely distributed in forests with native and introduced tree species and consisted of xylophagous generalist species that attack both live and dead wood. These species are a direct threat to local crops of introduced tree species, such as Eucalyptus spp., as well as the houses present in the study area. Some elements of medical-veterinary importance included spider species that are widely distributed in the country, such as those of the genera Loxosceles, Latrodectus, Sicarius, and Steatoda, all of which can cause necrotic and complex clinical symptoms in humans as a result of the neurotoxins contained in the venom. Triatoma infestans (Klug) and Mepraia spinolai (Porter) represent a threat to public health because they are potential foci of American trypanosomiasis whose reservoirs can be both the native and introduced species that are widely distributed in this basin. We hope that this information may be useful to characterize the biological vulnerabilities of the Limarí basin, particularly for the highly diverse, widely distributed taxa with potential implications for forestry and public health.

\section{Acknowledgments}

Our acknowledgments to Adiel R. Cayo (Servicio Agrícola y Ganadero, División de Protección Agrícola y Forestal) for allowing us access to data from SAG. Also, to Mario Elgueta (MNNC) and Danilo Cepeda (MEUC) for providing facilities to examine the collections, and two reviewers for suggestions for improving this paper. This study was funded by the DIDULS PR17121/VACDDI001 projects of Universidad de La Serena, La Serena, Chile (JPA).

\section{Resumen}

J. Pizarro-Araya, F.M. Alfaro, R. A. Muñoz-Rivera, J.E. Barriga-Tuñon, y L. Letelier. 2019. Artrópodos de importancia forestal y médico-veterinaria en la cuenca del Limarí (Región de Coquimbo, Chile). Cien. Inv. Agr. 46(1): 40-49. El valle del Río Limarí, en la Región de Coquimbo, es un importante foco de producción agrícola en los valles transversales del Norte Chico. En las últimas décadas, la constante expansión de los cultivos agrícolas hacia zonas de secano ha permitido la introducción y establecimiento de potenciales plagas, como los artrópodos, que pueden afectar las producciones forestales y constituir elementos zoonóticos. Se analizó la importancia forestal y médico-veterinaria de los artrópodos de la cuenca del Limarí. Mediante la revisión de bases de datos históricas, colecciones y literatura disponible, se registró un total de 10 familias, 39 géneros y 51 especies de artrópodos de importancia forestal, de las cuales el 43,1\% fueron de importancia cuarentenaria. Entre los elementos xilófagos de importancia cuarentenaria para EE.UU. destacaron los registros de Cryptotermes brevis (Kalotermitidae), Neoterius mystax (Bostrichidae), Tyndaris planata (Buprestidae), Rhyephenes 
humeralis (Curculionidae) and Phoracantha recurva (Cerambycidae). Otros insectos de importancia forestal reportados fueron Micrapate scabrata y Polycaon chilensis (Bostrichidae). Por su parte, los elementos de importancia médico-veterinario estuvieron representados por 11 familias, 14 géneros y 18 especies, de las cuales 9 especies correspondieron a arácnidos y 9 a insectos. Dentro de los arácnidos destacaron los géneros Loxosceles (Sicariidae), Latrodectus, Steatoda (Theridiidae) and Rhipicephalus (Ixodidae), mientras que dentro de los insectos las más importantes fueron Triatoma y Mepraia (Reduviidae), Pediculus (Pediculidae), y Ceratophyllus (Ceratophyllidae). Se espera que la información del presente estudio sirva de base para desarrollar programas de monitoreo y control de potenciales plagas forestales, así como también entender los potenciales riesgos de elementos zoonóticos con implicancias para la salud pública.

Palabras clave: Artrópodos, cultivos agrícolas, Norte Chico, Valle del Limarí, zonas áridas.

\section{References}

Alcayaga, O.E., J. Pizarro-Araya, F.M. Alfaro, and J. Cepeda-Pizarro. 2013. Arañas (Arachnida: Araneae) asociadas a agroecosistemas en el Valle de Elqui (Región de Coquimbo, Chile). Revista Colombiana de Entomología 39:150-154.

Álvarez, P. 2018. The water footprint challenge for water resources management in Chilean arid zones. Water International 43(6):846-859.

Alfaro, F.M., J. Pizarro-Araya, J. Cepeda-Pizarro, and A. Bodini. 2011. Composición y distribución del ensamble de Orthoptera (Insecta) en una cuenca árida del norte-centro de Chile. Revista de la Facultad de Ciencias Agrarias 43:97-110.

Canals, M., M.E. Casanueva, and M. Aguilera. 2004. ¿Cuáles son las especies de arañas peligrosas en Chile? Revista Médica de Chile 132:773-776.

Chacón, F., A. Bacigalupo, J.F. Quiroga, A. Ferreira, P.E. Cattan, and G. Ramirez-Toloza. 2016. Feeding profile of Mepraia spinolai, a sylvatic vector of Chagas disease in Chile. Acta Tropica 162:171-173.

DMC. 2001. Climatología regional. Dirección Meteorológica de Chile, Santiago, Chile. http://164.77.222.61/climatologia/publicaciones/Climatologia_regional.pdf (accessed 4 Apr. 2019)

EPPO (2019) EPPO Global Database. https:// gd.eppo.int (accessed 4 Apr. 2019)

Faúndez, E.I., and F. Téllez. 2016. Primer registro de una mordedura de Steatoda nobilis (Thorell,
1875) (Arachnida: Araneae: Theridiidae) en Chile. Arquivos Entomolóxicos 15:237-240.

Frías, D.A., A.A. Henry, and C.R. González. 1998. Mepraia gajardoi: a new species of Triatominae (Hemiptera: Reduviidae) from Chile and its comparison with Mepraia spinolai. Revista Chilena de Historia Natural 71:177-188.

Gajardo, R. 1993. La vegetación natural de Chile. Clasificación y distribución geográfica. Editorial Universitaria, Santiago, Chile.

González-Acuña, D., G. Valenzuela, L. Moreno, K. Ardiles, and A. Guglielmone. 2006. Nuevos hospedadores para las garrapatas Amblyomma tigrinum y Rhipicephalus sanguineus (Acari: Ixodidae) en Chile. Archivos de Medicina Veterinaria 38:273-275.

Lanfranco, D., and H.S. Dungey. 2001. Insect damage in Eucalyptus: A review of plantations in Chile. Austral Ecology 26:477-481.

Llinas-Gutiérrez, J., and M.L. Jiménez. 2004. Arañas de humedales del sur de Baja California, México. Anales del Instituto de Biología, México. Universidad Nacional Autónoma de México, Serie Zoología 75:283-302.

Matteucci, M.J., S.R. Williams, and R.F. Clark. 2005. Response to Latrodectus-associated compartment syndrome. Annals of Emergency Medicine 45:679-680.

Morales, L., F. Canessa, C. Mattar, R. Orrego, and F. Matus. 2006. Caracterización y zonificación edáfica y climática de la Región de Coquimbo, Chile. Revista de la Ciencia del Suelo y Nutrición Vegetal 6:52-74. 
Novoa, J.E., and D. López. 2001. IV Región: El escenario geográfico físico. In: Squeo, F.A., G. Arancio, and J.R. Gutiérrez (eds.). Libro Rojo de la Flora Nativa y de los Sitios Prioritarios para su Conservación: Región de Coquimbo, Chile. Ediciones Universidad de La Serena, La Serena, Chile. p. 13-28.

Ortiz, S., M.J. Ceballos, C.R. González, C. Reyes, V. Gómez, A. García, and A. Solari. 2016. Trypanosoma cruzi diversity in infected dogs from areas of the north coast of Chile. Veterinary Parasitology: Regional Studies and Reports 5:42-47.

Paine, T.D., M.J. Steinbauer, and S.A. Lawson. 2011. Native and exotic pests of Eucalyptus: A worldwide perspective. Annual Review of Entomology 56:181-201.

Parra, D., M. Torres, J. Morillas, and P. Espinoza. 2002. Loxosceles laeta, identificación y una mirada bajo microscopía de barrido. Parasitología Latinoamericana 57:75-78.

Pizarro-Araya, J., J. Cepeda-Pizarro, J.E. Barriga, and A. Bodini. 2009. Biological vulnerability in the Elqui valley (Coquimbo Region, Chile) to economically important arthropods. Ciencia e Investigación Agraria 36:215-228.

Romero, F., E. Altieri, C. Quiñehual, and A. Cayuqueo. 2000. Actividad contráctil de músculo papilar cardíaco y conducto deferente de rata inducido por veneno de la araña Lactrodectus mactans de Chile. Gayana 64:161-170.

Rosso, R.P., M.S. Ramírez, and M. Torres. 2003. Pediculus capitis: Terapias disponibles. Revista Chilena de Infectología 20:111-116.

Squeo, F.A., G. Arancio, and J.R. Gutiérrez. 2001. Libro Rojo de la Flora Nativa y de los Sitios Prioritarios para su Conservación: Región de Coquimbo. Ediciones Universidad de La Serena, La Serena, Chile.

Zambrano, A., J. González, and G. Callejas. 2005. Desenlace fatal por loxoscelismo cutáneo visceral. Revista Médica de Chile 133:219-223. 